\title{
ANALISIS STURKTUR KOGNITIF MAHASISWA PENDIDIKAN FISIKA PADA KONSEP STRUKTUR KRISTAL
}

\author{
Marungkil Pasaribu \\ Pendidikan Fisika, Universitas Tadulako, Palu, 94000 \\ Email: pasar67@yahoo.com
}

\begin{abstract}
Abstrak
Penelitian ini merupakan penelitian deskriptif kualitatif yang bertujuan untuk mendeskripsikan struktur kognitif mahasiswa pendidikan fisika yang terdaftar sebagai peserta pada mata kuliah Pend Fisika Zat Padat. Subjek penelitian berjumlah 38 orang. Instrument yang digunakan untuk mengetahui struktur kognitif mahasiswa adalah tes kata kunci, yakni, kisi, basis, struktur Kristal, unit sel, simetri Kristal, simple cubic (SC), body centered cubic (BCC), face centered cubic (FCC) dan Indeks Miller. Hasil analisis data menunjukkan bahwa struktur kognitif mahasiswa pada kata kunci simple cubic (SC), body centered cubic (BCC), dan face centered cubic (FCC) lebih lengkap dibanding dengaan kata kunci lainnya. Faktor yang mempengaruhi kurang lengkapnya struktur kognitif mahasiswa antara lain pengetahuan awal yang belum memadai serta sulit mendeskripsikan kata yang terdapat pada kata kunci.
\end{abstract}

Kata-kata Kunci: struktur kognitif, analisis, struktur kristal.

\begin{abstract}
This research was a qualitative descriptive study aimed to describe the cognitive structure of physics education students were registered in Introduction to Solid State Physics course. Subjects numbered 38 people. Instrument used to determine the cognitive structure of students is a Word association test such as lattice, bases, crystal structure, unit cell, the symmetry of crystals, simple cubic (SC), body centered cubic (BCC), face centered cubic (FCC) and the Index Miller. The result showed that the cognitive structure of students on keywords simple cubic (SC), body centered cubic (BCC), and a face centered cubic (FCC) is more complete than other keywords. Factors affecting less complete cognitive structures among other students' prior knowledge inadequate and difficult to describe the words contained in keywords.
\end{abstract}

Keywords: cognivtive structure, analysis, crystal structure

\section{Pendahuluan}

Pengetahuan merupakan akibat dari suatu konstruksi kognitif kenyataan melalui kegiatan seseorang. Proses pembentukan pengetahuan berjalan secara terus menerus dengan setiap kali mengadakan reorganisasi karena adanya suatu pemahaman yang baru. Pengetahuan bukanlah suatu barang yang dapat ditransfer begitu saja dari pikiran yang mempunyai pengetahuan ke pikiran orang yang belum mempunyai pengetahuan. Pembentukan pengetahuan menurut pandangan konstruktivisme menjadikan subyek aktif menciptakan struktur-struktur kognitif dalam interaksinya dengan lingkungan. Dengan bantuan struktur kognitif ini, subyek menyusun pengertian realitasnya. Interaksi kognitif akan terjadi sejauh realitas tersebut disusun melalui struktur kognitif yang diciptakan oleh subyek itu sendiri. Struktur kognitif senantiasa harus diubah dan disesuaikan berdasarkan tuntutan lingkungan dan organisme yang sedang berubah. Proses penyesuaian diri terjadi secara terus menerus melalui proses. Kreativitas dan keaktifan pebelajar akan membantu mereka untuk berdiri sendiri dalam kehidupan kognitifnya[1].

Pembentukan pengetahuan menuntut seseorang bertindak secara proaktif terhadap lingkungannya. Perkembangan struktur kognitif hanya bisa terjadi bila orang tersebut mengassimilasikan dan mengakomodasikan rangsangan dari luar yang dihadapi dalam pemikiran yang sudah dimilikinya. Melalui proses assimilasi seseorang mencoba untuk memahami lingkungannya menggunakan struktur kognitif yang 
sudah ada tanpa mengadakan perubahan-perubahan. Dengan proses akomodasi, seseorang mencoba memahami lingungannya dengan terlebih dahulu memahami struktur kognitif yang sudah ada untuk membentuk struktur kognitif yang baru berdasarkan rangsangan yang diterima.

Faktor yang paling berperan yang mempengaruhi proses pembelajaran adalah struktur kognitif dan apa yang telah diketahui seseorang. Agar pembelajaran bermakna, maka konsep baru harus dikaitkan dengan konsep-konsep yang ada dalam struktur kognitif. Proses belajar bermakna terjadi apabila ide-ide yang baru terhubung dengan struktur kognitif dan akan membentuk pengetahuan yang baru. Struktur kognitif merupakan bentuk rangkaian pemahaman seseorang dalam menangkap keterkaitan antara konsep yang satu dengan konsep yang lainnya membentuk sebuah rangkaian konsep yang bermakna. Tujuan mengetahui struktur kognitif adalah untuk mengetahui sejauh mana tingkat pemahaman seseorang terhadap suatu materi yang telah dipelajari. Mengetahui tingkat pemahaman mahasiswa pada suatu materi berarti mengetahui sejauh mana tingkat pengetahuan atau struktur kognitif mahasiswa pada suatu konsep yang telah diajarkan sebelumnya dan pengetahuan baru berdasarkan pengalaman. Makalah ini bertujuan untuk mendeskripsikan struktur kognitif mahasiswa prodi pendidikan fisika angkatan 2012 pada konsep struktur Kristal.

\section{Metode Penelitian}

Penelitian ini dilaksanakan pada mahasiswa Program studi Pendidikan Fisika Universitas Tadulako semester
VII tahun akademik 2015/2016 yang telah mengikuti mata kuliah Pend. Fisika zat padat. Subjek penelitian adalah mahasiswa angkatan 2012 yang berjumlah 38 orang. Pendekatan penelitian yang digunakan adalah penelitian kualitatif-deskriptif dimana semua data dikumpulkan berdasarkan fakta-fakta yang diperoleh dilapangan. Sumber data diperoleh dari subjek penelitian melalui tes dan wawancara. Instrument dalam bentuk tes kata kunci yang berkaitan dengan struktur Kristal. Tahapan yang dilakukan responden adalah menuliskan deskripsi dari kata kunci yang disediakan. Pemaparan mahasiswa tentang kata kunci kemudian dikelompokkan kedalam empat kategori, yakni deskripsi yang sesuai dengan konsep kata kunci, deskripsi yang tidak sesuai dengan konsep kata kunci, deskripsi yang mengarah kepada miskonsepsi, dan tidak ada deskripsi.

\section{Hasil dan Pembahasan}

Hasil analisis 9 kata kunci yang di berikan kepada mahasiswa yakni kata: kisi, basis, struktur kristal, unit sel, simetri Kristal, simple cubic (SC), body centered cubic (BCC), face centered cubic (FCC) dan Indeks Miller disajikan dalam tabel 1. Dari tabel terlihat bahwa sebahagian besar mahasiswa telah mampu memberikan penjelasan dengan baik dan benar, terutama pada konsep yang berkaitan dengan sistim Kristal yang di wakili kata kunci no 6,7 dan 8. Akan tetapi pada kata kunci no 9, sebahagian besar belum mampu memberikan deskripsi yang sesuai dengan konsep yang benar.

Tabel 1. Pengelompokan deskripsi jawaban responden pada masing-masing kata kunci

\begin{tabular}{|l|l|c|c|c|c|}
\hline \multirow{2}{*}{ No } & \multicolumn{1}{|c|}{ Kata Kunci } & $\begin{array}{c}\text { Desuai dengan Konsep } \\
\text { Kata Kunci }\end{array}$ & $\begin{array}{c}\text { Tidak sesuai dengan } \\
\text { konsep kata kunci }\end{array}$ & $\begin{array}{c}\text { Miskonsepsi } \\
\text { Tidak } \\
\text { ada }\end{array}$ \\
\hline 1 & Kisi & 25 & 9 & 1 & 3 \\
\hline 2 & Basis & 22 & 11 & 0 & 5 \\
\hline 3 & Struktur Kristal & 23 & 13 & 0 & 2 \\
\hline 4 & Unit sel & 22 & 10 & 1 & 5 \\
\hline 5 & Simetri Kristal & 21 & 7 & 0 & 3 \\
\hline 6 & Simple Cubic (SC) & 30 & 9 & 0 & 1 \\
\hline 7 & $\begin{array}{l}\text { Body Centered Cubic } \\
\text { (BCC) }\end{array}$ & 28 & 8 & 0 & 1 \\
\hline 8 & $\begin{array}{l}\text { Face Centered Cubic } \\
\text { (FCC) }\end{array}$ & 29 & 12 & 0 & 11 \\
\hline 9 & Indeks Miller & 15 & & & 0 \\
\hline
\end{tabular}

Untuk mengetahui struktur kognitif mahasiswa prodi pendidikan fisika pada konsep struktur Kristal digunakan kata kunci kisi, basis, struktur Kristal, unit sel, simetri Kristal, simple cubic (SC), body centered cubic (BCC), face centered cubic (FCC) dan Indeks Miller. Bila mahasiswa telah memberikan deskripsi dengan baik dan benar dari setiap kata kunci yang 
tersedia, maka mahasiswa tersebut dianggap telah memiliki struktur kognitif yang telah lengkap. Akan tetapi apabila penjelasan yang dituliskan belum sesuai dengan konsep yang baik dan benar maka mahasiswa tersebut dapat dikategorikan salah konsep atau miskonsepsi. Berikut ini akan dibahas struktur kognitif mahasiswa pada masing-masing kata kunci.

\section{Kata kunci Kisi.}

Berdasarkan pengelompokan deskripsi yang dituliskan mahasiswa diperoleh bahwa, sebanyak $66 \%$ mahasiswa telah menunjukkan struktur kognitif yang tepat. Secara umum mereka telah memahami konsep bahwa kisi merupakan sekumpulan titik-titik yang tersusun secara periodik dalam ruang. Terdapat pada beberapa lembar jawaban mahasiswa membuat gambar tentang kisi untuk menguatkan penjelasan yang mereka tuliskan. Namun, sekitar 24\% mahasiswa belum memahami secara baik dan benar tentang pengertian dari kisi. Mereka sebahagian memberikan deskripsi yang salah dan sebahagian lagi kurang lengkap. Dari hasil wawancara dengan responden terungkap bahwa mereka sulit membedakan antara kisi dan basis dan sebahagian lagi menyatakan lupa. Sekitar 2\% mahasiswa mengalami miskonsepsi dengan menyatakan bahwa kisi merupakan suatu molekul yang tersusun secara teratur dan berulang dan $7 \%$ tdk memberikan deskripsi.

\section{Kata kunci Basis.}

Untuk kata kunci Basis, hanya 58\% mahasiswa yang mampu memberikan deskripsi yang benar dan lengkap. Mereka mendeskripsikan bahwa basis merupakan atom atau sekumpulan atom. Penjelasan ini diperkuat lagi dengan menggambarkan hubungan antara kisi, basis dan struktur suatu Kristal. Deskripsi ini telah sesuai dengan konsep basis menurut para ahli. 29\% mahasiswa masih belum memahami sepenuhnya pengertian dari basis. Sebahagian menyatakan bahwa basis susunan dari molekul yang berulang dan teratur, dan sebahagian lagi menyatakan bahwa basis adalah kumpulan atom-atom. Hasil wawancara menunjukkan bahwa mereka ragu dalam memberikan deskripsi basis karena mereka belum bisa memahami secara jelas perbedaan antara kisi, basis dan kristal. Sekitar 13\% responden tidak memberikan deskripsi pada kata kunci ini dengan alasan mereka sudah lupa.

\section{Kata kunci struktur kristal.}

Sekitar $61 \%$ responden telah mampu mendeskripsikannya dengan benar. Mereka menyatakan struktur Kristal merupakan bentukan dari atom atau sekumpulan atom yang menempati titiktitik kisi. Responden juga memberikan beberapa contoh untuk menunjukkan pemahaman yang mendalam tentang struktur Kristal. Salah seorang responden memberikan contoh struktur Kristal, pada senyawa $\mathrm{H}_{2} \mathrm{SO}_{4}$, pada satu basis terdapat 7 atom. Terdapat $34 \%$ responden yang belum mampu mendeskripsikan kata kunci ini dengan benar. Dari hasil wawancara menunjukkan bahwa kekurang tepatan konsep yang dimiliki mahasiswa adalah dikarenakan responden belum memahami secara benar hubungan antara kisi, basis sebagai variabel penting dalam mendeskripsikan struktur Kristal.

\section{Kata kunci unit sel.}

Responden yang mampu mendeskripsikan kata kunci ini dengan benar hanyalah sebanyak $58 \%$. Mereka menyatakan bahwa unit sel merupakan sel satuan yang sisinya dibatasi oleh vektor translasi primitive yang memiliki volume terkecil. Sebahagian responden menggambarkan cara menentukan unit sel untuk memperjelas deskripsi yang dituliskan. Bahkan ada responden yang menggambarkan unit sel berdasarkan metode Wigenr Seizt. Akan tetapi masih terdapat $27 \%$ responden belum dapat memberikan deskripsi yang benar tentang kata kunci ini. Hasil wawancara menunjukkan, kegagalan mereka dalam memahami unit sel dikarenakan belum mengerti tentang cara menentukan vektor posisi. Sebahagian dari mereka mengalami miskonsepsi (2\%) dan bahkan terdapat $13 \%$ tidak memberikan deskripsi dengan alasan lupa.

\section{Kata kunci Simetri kristal.}

Berdasarkan kalimat yang dituliskan responden untuk tes kata kunci ini terlihat bahwa hanya 55\% yang telah dapat memberikan deskripsi secara benar. Mereka mendeskripsikan bahwa simetri adalah operasi transformasi untuk memberikan sesuatu yang mirip dengan yang beroperasi. Ada juga yang mendeskripsikan bahwa simetri kristal adalah suatu hasil operasi yang apabila dilakukan pada kristal yang memiliki simetri tersebut menghasilkan suatu keadaan baru yang tidak dapat dibedakan dari keadaan sebelumnya. Beberapa responden juga memberikan penjelasan dengan mendeskripsikan beberapa jenis simetri seperti simetri rotasi, simetri cermin atau simetri inversi. Tetapi masih terdapat $18 \%$ responden yang belum memiliki struktur kognitif yang benar pada kata kunci ini. Dari hasil deskripsi yang mereka tuliskan dan hasil wawancara terlihat bahwa secara umum responden ini belum memahami unsur-unsur simetri pada kristal.

\section{Kata kunci simple cubic (SC).}

Berdasarkan pengelompokan deskripsi yang dituliskan mahasiswa diperoleh bahwa, sebanyak 79\% mahasiswa telah menunjukkan struktur kognitif yang tepat. Secara umum mereka telah memahami konsep bahwa simple cubic (SC) merupakan tipe Kristal kubus yang sederhana, dimana pada setiap pojoknya terdapat sebuah atom, panjang kisia = panjang kisi $b=$ panjang kisi c serta sudut $\alpha=$ sudut $\beta$ $=$ sudut $\gamma=\pi / 2$. Responden juga memberikan deskripsi dengan detail tentang ciri-ciri Kristal SC ini seperti: menuliskan volume sel satuan, menentukan jumlah kisi persel, menuliskan vector primitive serta menuliskan contohnya. Responden secara umum telah 
memiliki pemahaman yang baik terhadap kata kunci ini. Akan tetapi masih terdapat sekitar $18 \%$ responden belum memahami secara baik dan benar tentang pengertian dari kata kunci ini. Dari hasil wawancara terlihat, responden masih belum bisa membedakan sistim Kristal SC, BCC dan FCC.

\section{Kata kunci body centered cubic (BCC).}

Untuk kata kunci body centered cubic, hanya $74 \%$ mahasiswa yang mampu memberikan deskripsi yang benar dan lengkap. Mereka mendeskripsikan bahwa tipe Kristal body centered cubic (BCC) adalah bila titik kisi berada pada setiap pojok ditambah dengan sebuah titik kisi pada diagonal ruangnya, panjang kisi $\mathrm{a}=$ panjang kisi $\mathrm{b}=$ panjang kisi $\mathrm{c}$ serta sudut $\alpha=$ sudut $\beta=$ sudut $\gamma=\pi / 2$. Untuk mendukung deskripsinya, mereka menuliskan ciri-ciri Kristal BCC ini seperti: menuliskan volume sel satuan, menetukan jumlah kisi persel, jumlah tetangga terdekat, menuliskan persamaan vektor primitif serta menuliskan contohnya. Responden secara umum telah memiliki pemahaman yang baik terhadap kata kunci ini. Deskripsi ini telah sesuai dengan konsep BCC menurut para ahli. Masih terdapat $24 \%$ mahasiswa masih belum memahami sepenuhnya tentang kata kunci ini.

\section{Kata kunci face centered cubic (FCC)}

Sekitar $76 \%$ responden telah mampu mendeskripsikan kata kunci ini dengan benar. Mereka menyatakan bahwa FCC merupakan tipe Kristal jika pada setiap pojok dan pada setiap diagonal bidang sisi terdapat titik kisi, panjang kisi $\mathrm{a}=$ panjang kisi $\mathrm{b}=$ panjang kisi c serta sudut $\alpha=$ sudut $\beta=$ sudut $\gamma=\pi / 2$. Responden juga memberikan deskripsi dengan detail tentang ciri-ciri Kristal BCC ini seperti: menuliskan volume sel satuan, menetukan jumlah kisi persel, jumlah tetangga terdekat, menuliskan persamaan vektor primitif serta menuliskan contohnya. Deskripsi ini telah sesuai dengan konsep FCC menurut para ahli. Namun, masih terdapat $22 \%$ mahasiswa masih belum memahami sepenuhnya tentang kata kunci ini.

\section{Kata kunci Indeks miller.}

Hanya sebanyak 39\% responden yang mampu mendeskripsikan kata kunci ini dengan benar. Mereka menyatakan bahwa indeks miller berfungsi sebagai alat untuk menyatakan orientasi bidang kristal dengan system indeks bidang. Indeks Miller tidak hanya menunjukkan satu bidang saja, melainkan menunjukkan semua bidang yang sejajar dengan bidang tersebut adalah jarak antara dua bidang berturut-turut. Kelompok responden ini telah memahami secara jelas cara menentukan indeks miller suatu bidang Kristal melalui pernyataan yang dituliskan bahwa untuk menyelidiki indeks miller harus terlebih dahulu memahami posisi titik dalam sel, arah vector dan orientasi bidang. Untuk memperjelas deskripsinya, responden ini juga menggambarkan sel konvensional untuk kubus sederhana, memberikan irisan pada bidang Kristal yang disertai dengan indeks bidangnya. Akan tetapi sebahagian besar responden belum memiliki struktur kognitif yang lengkap dalam mendeskripsikan kata kunci ini. Hal ini terlihat dari persentase responden (61\%) memberikan deskripsi yang tidak benar, dan bahkan sekitar 29\% responden tidak memberikan deskripsi terhadap kata kunci ini. Hasil wawancara menunjukkan bahwa responden yang tidak memberikan deskripsi pada kata kunci ini karena tidak memahami arti kata indeks miller, tidak mengetahui bagaimana cara menentukan indeks bidang yang dimaksudkan, serta lupa.

Hasil penelitian dengan menggunakan tes kata kunci (WTA) dan wawancara menunjukkan bahwa struktur kognitif mahasiswa pada konsep struktur Kristal masih belum lengkap. Dugaan penyebab kurang lengkapnya struktur kognitif mahasiswa dikarenakan dalam proses pembelajaran mereka cenderung menghafal konsep semata. Dalam proses pembelajaran yang lebih menekankan pada resitasi pada konten, tanpa memberikan waktu yang cukup kepada mahasiswa untuk merefleksikan materi-materi yang dipresentasikan, menghubungkan dengan pengetahuan sebelumnya, atau mengaplikasikannya kepada situasi kehidupan nyata[2]. Akibat proses pembelajaran yang tidak tepat ini adalah kurangnya pemahaman mahasiswa terhadap materi, kesimpulan yang salah dan bahkan terdapat beberapa responden tidak memberikan deskripsi [3] serta mengalami miskonsepsi[4] pada masing-masing kata kunci.

\section{Simpulan}

Berdasarkan hasil penelitian dan pembahasan yang telah di uraikan dapat disimpulkan bahwa persentase struktur kognitif mahasiswa dengan menggunakan WTA pada konsep struktur Kristal secara berturut-turut adalah: kata kunci kisi (66\%), basis (58\%), struktur Kristal (58\%), unit sel (58\%), simetri Kristal (55\%), simple cubic (SC) (79\%), body centered cubic (BCC) (74\%), face centered cubic (FCC) $(76 \%)$ dan Indeks Miller (39\%). Faktor yang mempengaruhi kurang lengkapnya struktur kognitif mahasiswa antara lain pengetahuan awal yang belum memadai serta sulit mendeskripsikan kata yang terdapat pada kata kunci.

\section{Ucapan Terimakasih}

Diucapkan terimaksih kepada Lembaga Penelitian Untad yang telah mendanai penelitian ini dalam kegiatan penelitian Hibah Bersaing dengan Surat Perjanjian Penugasan Nomor: 8080/UN28.2/PL/2016 Tanggal 22 Februari 2016. 


\section{Daftar Acuan}

[1] P. Suparno, Filsafat konstruktivisme dalam pendidikan, Yogyakarta, Kanisius (1997), p. 17 $-29$

[2] S. Shoimatul Ula, Revolusi Belajar: Optimalisasi kecerdasan melalui pembelajaran berbasis kecerdasan majemuk, Yogyakarta, ArRuzz Media (2013), p 33 -35.

[3] P. Suparno, Teori perkembangan kognitif Jean Piaget, Yogyakarta, Kanisius (2001), p. 139 154.

[4] S. Timur, Examining cognitive structures of prospective preschool teachers concerning the subject "Force and Motion"., Educational Sciences: Theory \& Practice, Autumn p.(30393049) 
